\title{
James Baldwin: Biographical Dispatches on a Freedom Writer
}

\author{
Phillip Luke Sinitiere Sam Houston State University
}

\begin{abstract}
This essay presents the idea of James Baldwin as a freedom writer, the organizing idea of my biography in progress. As a freedom writer, Baldwin was a revolutionary intellectual, an essayist and novelist committed unfailingly to the realization of racial justice, interracial political equality, and economic democracy. While the book is still in process, this short essay narrates autobiographically how I came to meet and know Baldwin's work, explains in critical fashion my work in relation to existing biographies, and reflects interpretively my thoughts-in-progress on this fascinating and captivating figure of immense historical and social consequence.
\end{abstract}

Keywords: James Baldwin, biography, American culture, African-American history, black radicalism

Jimmy is terrifying ... Because he demands of anybody who comes in contact with him a look at some aspect of truth. How the hell do I say this? - Jimmy confronts you, not just racially, but with the human predicament.

Kenneth B. Clark (1966) ${ }^{1}$

One of the last things [Baldwin] said to me was that he hoped that I and other writers would continue to be witnesses of our time; that we must speak out against institutionalized and individual tyranny wherever we found it. Because if left unchecked, it threated to engulf and subjugate us all-the fire this time. And, of course, he is right. He is right-about racism, violence, and cynical indifference that characterize modern society, and especially the contemporary values that are dominant here in America today.

Quincy Troupe (1987) $)^{2}$

In late 2005, I met James Baldwin for the first time. That fall, my final semester of Ph.D. coursework at the University of Houston, Gerald Horne, a scholar of black

James Baldwin Review, Volume 2, 2016 @ The Authors. Published by Manchester University Press and The University of Manchester Library 
radical politics, commended Baldwin to the dozen of us enrolled in his seminar on twentieth-century African-American history. I do not remember if Professor Horne recommended a specific title of Baldwin's to read. Rather, my recollection is that Baldwin's name and ideas surfaced time and again in the midst of discussions about black radicalism. Baldwin, in some measure, informed how my classmates and I sought to make sense of works like Tim Tyson's Radio Free Dixie, or grapple with Robin D. G. Kelley's Hammer and Hoe. Baldwin's memory intersected with conversations about Barbara Ransby's Ella Baker and the Black Freedom Movement and even more so the week we read Steve Estes' I Am a Man! ${ }^{3}$

As the name of James Baldwin became more familiar to me throughout that semester, I ventured to the third floor of M. D. Anderson library and wandered in the stacks until I got to the shelves that housed his work. Two books quickly grabbed my attention: David Leeming's James Baldwin: A Biography and James Baldwin: Collected Essays, one of three Library of America volumes devoted to the writer. While Leeming's book provided historical context and an unfolding narrative of Baldwin's life, the necessary groundwork for a historian-in-training, at that moment the Collected Essays struck my imagination. The words leapt off the page and scrambled my thinking. The affective intensity of Baldwin's prose moved me to tears, stirred frustration, brought enlightenment, and conjured hope. I read Notes of a Native Son and Nobody Knows My Name first followed by The Fire Next Time. Then I tackled several of the essays: "Sermons and Blues," "A Talk to Teachers," "History as Nightmare," "White Racism or World Community?," and "The White Man's Guilt." Passages compelled me to re-read them; in other moments, I simply had to set the book down as the ideas provoked numerous soul-stirring moments of reflection about religion, economics, race, and sexual identity. In those moments - in my late twenties-sitting with James Baldwin I slowly began to realize my whiteness, and grapple with what white male privilege had meant in my life up to that point. A striking passage in “The White Man's Guilt" still resonates today, as much for its piercing critique of white supremacy as its imperative to understand and grapple with history:

The fact that they have not yet been able to do this-to face their history, to change their lives-hideously menaces this country. Indeed, it menaces the entire world. White man, hear me! History, as nearly no one seems to know, is not merely something to read. And it does not refer, merely, or even principally, to the past. On the contrary, the great force of history comes from the fact that we carry it within us, are unconsciously controlled by it in many ways, and history is literally present in all that we do. ${ }^{4}$

Yet Baldwin's words did not suffocate me with white guilt. Page after page in that slim green volume of Collected Essays demanded that I both understand and recognize how entrenched, structural white supremacy not only scarred the souls and psyches of African people in the United States, but also how it scourged the souls and psyches of white people. White supremacy, I heard Baldwin say, was not just about an individual's reckoning with injustice. It involved a deeper awareness of systemic inequality, and active agitation for economic democracy and racial 
justice. It demanded a certain kind of conscious divestment of whiteness-to the extent this is possible for white bodies. Baldwin's work, therefore, as I began to read and re-read it over a decade ago, indicted my whiteness while it inspired new questions about society and instigated ways of being in the world that embodied deep solidarity in the name of black freedom. My activist self asked, "What can I do?" and "What must I do?" My academic self said, "I must write about this."

The more I read Baldwin, the more he challenged my thinking and spawned a commitment to revolutionary justice. I longed to write something about him, but the timing was never right. I had a dissertation to complete, and shortly thereafter a new teaching job, associated responsibilities, and other writing projects. However, in late 2014, an opportunity to write a biography of Baldwin materialized; the timing finally felt right. In early 2015, I signed a contract with Rowman and Littlefield to contribute a book to the Library of African-American Biography series. While the book is still in process this short essay narrates how I came to meet and know Baldwin's work, and reflects my thoughts-in-progress on this fascinating and captivating figure of immense historical and social consequence.

As it happened, I found myself in Paris in March of 2009. I was a high school history teacher at the time, and was one of the chaperones on an international excursion with my school's French program. Knowing that Baldwin spent substantial parts of his life in France, I traveled with the Collected Essays. During a moment of free time, I sat on a rainy, cool, and quiet morning in a café reading James Baldwin. I imagined Jimmy traveling through the city, the course of his interesting life intersecting with global realities in a global metropolis. I endeavored to grasp how Baldwin's time in France shaped and re-shaped his cogent critiques of white supremacy. So there in the café I wrote poetry about Baldwin and his work, the first time I ever penned something about the insurgent black writer. Shuffling through my Baldwin research files as I wrote this essay, I found "Sitting with Jimmy," dated 10 March 2009. "Sitting with Jimmy/ In a Paris café/ On a cold, damp, dreary day/ As the music plays ... I wish Jimmy was here/ We sit and The Devil Finds Work/ I listen to The Fire Next Time/ Jimmy speaks to the ages/ St. James, where art thou?" Amateur verse, to be sure, but it marked a longing to hear and feel Baldwin's work in a new, international key. "Sitting with Jimmy" represents an archival fragment of my intellectual and existential journey with Baldwin's work as I have researched and written the biography. In retrospect, "Sitting with Jimmy" was one attempt to humanize Baldwin, something which subsequent archival research further allowed me to capture.

In the summer of 2014, upon commencing a research trip to the east coast, I found myself at the Schomburg Center for Research in Black Culture and then at the University of Massachusetts Amherst (UMass). While in these archives, I learned more about Baldwin the writer, intellectual, and cultural critic. I also caught glimpses of Baldwin the human being. In New York City, combing through the letters, typescripts, and pages of his diary, I found a February 1979 letter Baldwin had written to his brother David. Presumably, a reflection upon finishing what was his final novel, Just Above My Head, Baldwin wrote: 
When a book is over, you always feel you missed it. There is always what you did not see. On the other hand, only the effort-the looking backward on the voyage-shows you what you did not see. Which means that you now see something, which you did not see before. Or did not dare to see. I am not satisfied with my novel, at all. It is much more a lyric, than the mighty song I heard. Still, I hear the song more than ever.

Even after he completed works, Baldwin continued to wrestle with words and ideas. He aimed to capture life's complexities, and bear witness to how humanity and love might conquer the depths of struggle and death; this is the voyage about which Baldwin wrote to David. As David Leeming wrote about Just Above My $\mathrm{Head}$, the book showed that "Baldwin was still obsessed by a mission that knew no boundaries." ${ }^{\text {" }}$

Sitting in the quiet reading room on the twenty-fifth floor of the W. E. B. Du Bois Library at UMass, looking through several boxes of unprocessed records from the W. E. B. Du Bois Department of Afro-American Studies, I searched for materials related to Baldwin's stints in the mid-1980s as a visiting professor in western Massachusetts. To my intellectual delight, I found a syllabus from one of Baldwin's courses as well as articles from The Collegian, UMass's campus newspaper, along with materials from memorial services held after his death. About Baldwin's class in the spring of 1986 titled "The Afro-American Cultural Experience," the Du Bois department deemed that "essential to the course will be the reading of Mr. Baldwin's own works. Mr. Baldwin will lecture on Tuesdays. Discussion sections will meet on Thursdays." Leading black scholars Michael Thelwell, Ernest Allen, and Esther Terry served as discussion section leaders in Baldwin's course. Baldwin's lectures used his own life to narrate the nineteenth- and twentieth-century's black freedom struggles both in the United States and abroad. The course coupled a meditation on Uncle Tom's Cabin and A Tale of Two Cities with reflections on life in Harlem. It considered David Walker's Appeal, Frederick Douglass, Toussaint L'Ouverture, Nat Turner, and Sojourner Truth before an examination of anticolonialism, and through The Fire Next Time the importance of "Malcolm and Muhammad." The course finished with weeks devoted to Black Power and women's literature, and a final lecture titled "Jesse Jackson and Farrakhan: The Politics of Black Religion." Baldwin died the following November, and his friends and colleagues in Amherst hosted a program in recognition of his achievements on 16 December 1987, "We Have Seen His Righteous Witness." In reflection of Baldwin's life, Esther Terry stated at the memorial service, "We want to express a deep feeling of sorrow, and also jubilation, that James Baldwin lives, and will continue to live."

I had first met Baldwin as a writer through the Collected Essays, then as a teacher in historical records of his tenure at UMass. Baldwin as a human being converged with Baldwin the freedom writer. My label of Baldwin as a freedom writer plays on the Freedom Riders, Congress of Racial Equality (CORE) and Student Nonviolent Coordinating Committee (SNCC) organizers and activists who in 1961 led freedom rides on buses through hostile territory in the American South. At a time of increasing opposition toward freedom fighters who staged sit-ins, 
kneel-ins, and boycotts, CORE and SNCC's initiatives to dismantle segregation brought national media attention to the fight. This direct action strategy ultimately succeeded in desegregated busing across interstate travel even as it revealed generational and tactical fissures within the broader black freedom struggle. I envision Baldwin's scathing assaults on white supremacy and bold confrontation with injustice as a freedom writer as a kind of contemporaneous rhetorical direct action that paralleled the unflagging commitments of the Freedom Riders, and also like the youthful activists, scored violent reactions to his work. ${ }^{7}$

In addition to recently published primary source materials in Randall Kenan's edited The Cross of Redemption: Uncollected Writings and Jimmy's Blues and Other Poems, the availability of digital materials online has added another avenue through which to research his life. For example, the San Francisco Bay Area Television Archive housed at San Francisco State University several years ago made available the 1964 film Take This Hammer. Shot in 1963 as KQED filmed Baldwin's travels around San Francisco, the documentary presents legacies of the Great Migration to northern California, intense class conflict on the west coast, and the impact of white supremacy during a signature year in the black freedom struggle. The film also documents Baldwin's running commentary and political analysis, footage that visually captures the intensity of his ideas as well as his mannerisms, and the cadence of his voice. The footage of Take This Hammer brings Baldwin to life in a way that visually complements the passion and verve found in his writing. In addition, Pacifica Radio Archives have also digitized a number of Baldwin's speeches, most of which date to the 1960s. The act of seeing Jimmy Baldwin and hearing his voice is no small thing for contemporary Baldwin scholars, most of whom-unlike his earliest biographers-never met him. ${ }^{8}$

After my initial encounter with Baldwin through his words on the printed page, a visit to Paris brought a new dimension to thinking about his work and influence. As a scholar and a teacher, I stress the instructional and existential vitality of an onsite presence for greater historical understanding. Obtaining a visual and spatial sense of the city Baldwin, not to mention other U.S.-based AfricanAmerican writers, intellectuals, and artists, once traversed, I found that as a result of my travel I could better grasp his life abroad and the transatlantic shape of his global intellectual horizon. Archival research also broadened my perspective and humanized him, especially aspects of Baldwin the professor and teacher, and added a great deal to making sense of his life's totality. Such personal experiences with Baldwin sites and the literal archival, historical record of his life speak to only one part of a biographer's task. Interpreting his life and writings in biographical mode presents another exciting challenge in the historical reconstruction of such an important and complex individual.

While generally united in admiration, the scholarship on Baldwin's life over the past half-century is poles apart from what his life means. A certain binary shapes academic reflection on Baldwin. For many scholars Baldwin is a black writer, for others his work is foundational for understanding black queer culture. Still other writers consider the work of Baldwin the black playwright, or Baldwin the black 
cultural critic. The bottom line is that for many Baldwin must be this or that, resulting in what the late scholar Conseula Francis called "critical devotion and critical neglect." "While this is the likely lot for someone as complex as Baldwin, such interpretive directions likely stem from a four-decade public career and a globetrotting existence. In short, James Baldwin is notoriously difficult to synthesize, which makes analysis of his work supremely exhilarating. This reality has produced what Francis termed a "Baldwin renaissance." ${ }^{10}$ Similarly, in recognition of Baldwin's broad-ranging work, scholar Douglas Field writes, "It is only by paying attention to Baldwin's developing rather than fixed views, his ideological shuffles and even his outright contradictions, that his large body of writing begins to cohere." 11

Indexes of this critical opinion emerge when we consider the leading biographies of Baldwin. One biography appeared during Baldwin's lifetime-Fern Marja Eckman's 1966 The Furious Passage of James Baldwin-and five since 1990: William J. Weatherby's James Baldwin: Artist on Fire (1990); James Campbell's Talking at the Gates (1991); David Leeming's James Baldwin: A Biography (1994); Randall Kenan's James Baldwin (1994, 2005); and Herb Boyd's Baldwin's Harlem: A Biography of James Baldwin (2008).

Eckman's book succeeds admirably with judicious quotes from hours of interviews with Baldwin, and describes his life, mind, and mannerisms in artful prose. Two examples illustrate Eckman's descriptively rich book. "It is Baldwin's conviction that none of us in the United States, regardless of individual attitude and the blamelessness of our deeds, can really be judged innocent," Eckman writes. "We have all of us, he reiterates, contributed in some degree to the subjugation of a people, passively or actively, overtly or covertly, consciously or unconsciously. And it is this thesis that makes so many squirm." ${ }^{2}$ The complexity of Baldwin's identity, Eckman observes, reveals the depth of his experiences as both black and American.

He is a distillation of the nation's experience as well as his own. Talking of whites and Negroes, writing about them, he wavers between first person plural and the third. But his duality reflects his country's. Growing up in a culture that is neither all white nor all black, he assimilated both parts ... Inevitably, as the penalty of his success, he is castigated by many white Americans as an extremist and flailed by more radical Negroes as a moderate. ${ }^{13}$

The essence of Baldwin's conflicted identity, Eckman's comments suggest, is precisely what empowered his confident denunciations of America's racial divide. And while the book's strength is that it captures Baldwin at a considerably important moment in his life and career - the mid-1960s - that is the very thing that limits it. Eckman's book is a document firmly fixed in the 1960s. Built upon Baldwin's celebrity during that decade, it provides an oral history of a public Baldwin, a vital source in the writer's biographical archive.

Baldwin biographies that appeared in the 1990s and after offer fuller accounts of the writer's life. The passage of time and Baldwin's continued literary and intellectual production, along with an active attempt to assess his emerging legacy, offered more to digest, study, and analyze. 
Weatherby's book provides details and minutiae of Baldwin's everyday existence, whereas Campbell's study locates Baldwin within the larger national and international contexts of which his life was a part. Weatherby crafts a careful, humanizing portrait of Baldwin, illuminating the network of friends and family, including the actor Marlon Brando, as well as activist friends, academics, and comrades such as Michael Thelwell, on whom Baldwin depended for emotional sustenance and overall human companionship. Kenan's biography, a popular account of the writer aimed at a younger audience, frames Baldwin's life around his existence as a gay black man. Kenan recounts Baldwin's groundbreaking decision to produce fictional tales of real struggles about sexual identity in an unwelcoming culture, and describes the author as "fearless in his writing"; "With his refusal to be defined or to follow literary traditions ... [he] helped create a space for future African-American gay writers." ${ }^{14}$ Kenan's positive profile of Baldwin also rendered lessons and takeaways to account for the black writer's legacy: "Baldwin believed in order to create a just world, people must know and admit their history, and to free their hearts of hatred."15

Less laudatory toward Baldwin than Weatherby's book, and in marked contrast to Kenan's sympathetic coverage of Baldwin's life, Campbell's Talking at the Gates vividly presents the circles in which Baldwin moved as an intellectual, essayist, playwright, and celebrity. Like Eckman, Campbell captures the writer's language and mannerisms, but also offers a probing mental profile of Baldwin. "Baldwin was as notoriously unreliable in his personal relationships as he was famous as a charmer, a moralist, a preacher. He also had a paranoid fear of being patronized, especially by whites (which played a part in his dedication to courting them)."16 While capturing the existential indignities of white supremacy on an interpersonal level, Campbell explains that white supremacy's blade cut to the heart of Baldwin's being as assassinations of black leaders mounted throughout the 1960s. Baldwin feared he would be next, Campbell writes, due to an overinflated imagination that placed the writer in the upper crust of civil rights leadership. "Baldwin's exaggeration can be regarded as a symptom of the devastation which King's death wrought inside of him," Campbell explains. "If he inflated his importance within the top echelon of the black leadership, it was to help prop up a spirit that died a little each time a limb of that leadership was broken off."17 In retrospect, the popularity of psychoanalysis in the late twentieth century is one element that ties Weatherby and Campbell together. Intimate portraits by each author-part psychological profile, part emotional analysis-invite readers to observe the complex and contradictory humanity that fueled James Baldwin, inspired his ideas, and energized his work.

Leeming's book is the strongest of all the biographies. A longtime friend and assistant to Baldwin, Leeming paints a gripping intellectual and social profile of the writer and powerfully sets major works and publications in broader historical context. Whereas Eckman and other biographers observed Baldwin's mannerisms and habits of mind, Leeming knew Baldwin; he thus captures movingly Baldwin's moods and thoughts over the course of his distinguished life. In both historical and literary depth, Leeming accounts for religious, humanistic sensibilities with which 
Baldwin grappled about the world's injustices, and accents the book's highly readable, narrative flow with meaningful literary insights into Baldwin's vast archive. Also notable, and unique among most of Baldwin's biographers except Campbell, Leeming's volume includes a beautiful collection of black and white photographs, a memorable visual accompaniment to the textual rendering of Baldwin's life. ${ }^{18}$

Boyd's study is more limited in scope in its specific focus on Harlem, but its depth parallels Leeming's detailed portrait of Baldwin as it considers the place of Harlem throughout the writer's lifetime. Through coverage of the Harlem Renaissance, Boyd's book connects Baldwin to figures such as Countee Cullen and Langston Hughes, along with the area's black freedom movement expressed in the activities of Malcolm X and the political writing of Amiri Baraka. While Baldwin traveled the world and spent a good part of his life outside of New York City, Boyd effectively links Harlem-its image, memory, and imaginative presenceto the full scope of Baldwin's life and times. Unlike other biographers, Boyd includes interviews he conducted with people intimately familiar with Baldwin, Michael Thelwell and Quincy Troupe. The result is a unique historical record that biographically memorializes the black writer. ${ }^{19}$

Several notable things stand out about these volumes. First, it is astonishing that only six biographies exist on a figure of Baldwin's stature. Surely, his significance warrants considerably more attention, which in many ways the vast and growing Baldwin scholarship represents. At the same time, the appearance of Baldwin biographies since 1990 suggests the sustained salience of his work. Second, the majority of his biographers knew Baldwin personally, and their lives overlapped with his for significant periods of time. This offered for each author a distinct investment in the subject and person of James Baldwin, perhaps none more so than David Leeming who worked closely with him for many years. The upshot of this proximity to the subject matter resulted in deeply human and largely compelling portraits of Baldwin. Unlike most other Baldwin biographers, I never knew Baldwin personally. Although our lives overlapped by only a decade-I was ten years old when Baldwin died and did not discover his work until graduate school-as I related earlier I have attempted to engage Baldwin in ways that seek to bring his work to life.

My biography stands on the shoulders of previous Baldwin scholars. It is a synthetic work, a short, 200-page, undergraduate-friendly book aimed at a popular audience. Designed as an introductory text, my book will present a broad narrative of Baldwin's life in the United States and abroad that connects his major literary works, essays, and reviews to their historical and cultural contexts. While not a literary analysis of his corpus in the traditional sense, my biography conceives of Baldwin as a freedom writer and black radical, an intellectual agitator whose ideas and life prized self-determination, economic democracy, and political equality. As a freedom writer, Baldwin's words mattered as much as his ideas, especially in his concerns over both race and class. ${ }^{20}$

Conceiving of Baldwin as a freedom writer, I seek to emphasize that freedom for Baldwin was neither a philosophical nor a political abstraction. Similar to the Freedom Riders who dared to put their lives on the line and place their humanity in 
harm's way, Baldwin's freedom writing is of material significance, and it is embodied. Baldwin, I contend, fleshed freedom out not just in printed text on a page but also through the power of words and the humanity of blackness from which his words and ideas came. Baldwin attempted to write about freedom, and wrote himself to freedom as he imagined liberation and gave voice to liberty. Baldwin as a freedom writer conjoined the existential with the material; his work gave words figural hands and feet, fingers and limbs, lips, tonality, voice, ears, and eyes. Conceptualizing Baldwin as a freedom writer is as much about the power of his ideas as it is about the political play of the printed word. Baldwin as freedom writer entangles the intimate, interior dimensions of his life that Eckman alerted us to with the psychological habits of mind Weatherby and Campbell's work disclosed. It stitches the fuller human portrait of Baldwin with which Leeming treats his subject's life to the intense locality of Harlem that informed, shaped, and in some ways haunted and chased Baldwin over the course of his lifetime. Connecting the biographical dots of James Baldwin the freedom writer imagines a panoply of patches that form a quilt, a multiplicity of patterns that constitutes a complex whole.

The convergence of Baldwin's words and ideas in many ways found their fullest manifestation in his speeches and presentations, in his human expressions, especially in his later years. The performative dimensions of Baldwin's freedom workthe power of his presence and his spoken words-is another topic that my book will address. Amiri Baraka and Toni Morrison captured this facet of Baldwin's life. A cold winter's day descended on the Cathedral of Saint John the Divine in late December 1987 for Baldwin's funeral. Yet a warm glow of deep affection enveloped those who came to pay tribute to his remarkable life at the New York City church. Among other speakers, black poet and writer Amiri Baraka delivered a moving eulogy for his deceased friend. Baraka described Baldwin as a "glorious, elegant griot of our oppressed African American nation,"21 praised his kindness, passion and the razor-sharp ethical edge of his writing and speaking. He described Baldwin's career-long prophetic rage against injustice while reminding those present that wrapped in Baldwin's accusations against the U.S. was a genuine hope in the realization of democratic equality. Baraka praised both Baldwin's ideas and words. "Jimmy will be remembered," Baraka stated,

for his word. Only the completely ignorant can doubt his mastery of it. Jimmy Baldwin was the creator of contemporary American speech even before Americans could dig that. He created it so we could speak to each other at unimaginable intensities of feeling, so we could make sense to each other at yet higher and higher tempos. ${ }^{22}$

For Baraka, Baldwin's words registered powerfully in his performative elocutions.

But that word, arranged as art, sparkling and gesturing from the page, was also man and spirit. Nothing was more inspiring than hearing that voice, seeing that face, and that whip of tongue, that signification that was his fingers, reveal and expose, raise and bring down, condemn or extol! ${ }^{23}$ 
At the end of his speech, Baraka called for a robust reckoning with Baldwin's life and career. He pled with the audience to honor Baldwin's legacy by redoubling efforts at self-determination in the service of justice.

Let us hold him in our hearts and minds. Let us make him part of our invincible black souls, the intelligence of our transcendence. Let our black hearts grow big worldabsorbing eyes like his, never closed. Let us one day be able to celebrate him like he must be celebrated if we are ever to be truly self-determining. For Jimmy was God's black revolutionary mouth. ${ }^{24}$

Equally powerful, Morrison commented on the vibrancy of Baldwin's language, which she connected to a fierce ethical commitment to freedom. "No one possessed or inhabited language for me the way you did," Morrison remarked.

You made American English honest-genuinely international. You exposed its secrets and reshaped it until it was truly modern, dialogic, representative, humane. You stripped it of ease and false comfort and fake innocence and evasion and hypocrisy. And in place of deviousness was clarity. In pace of soft plump lies was lean, targeted power. ${ }^{25}$

As a freedom writer, not unlike some of the original Freedom Riders, Baldwin was a revolutionary intellectual, an essayist and novelist committed unfailingly to the realization of racial justice, interracial political equality, and economic democracy. In today's global world in which cultural pluralism and racial and ethnic diversity remain important topics of discussion and flashpoints of controversy, Baldwin's work is as timely as ever. From Baldwin's heart, mind, and mouthoftentimes literally-emanated a radical ethic of love that aimed to dismantle and overturn white supremacy. Far from an ethereal feeling, love in Baldwin's body of work gave voice to the disinherited while it simultaneously assaulted conservatives and discomforted liberals. In this way, Baldwin was the prophet of justice many called him; he was also a self-proclaimed witness to justice. As Baraka beautifully described, Baldwin's “world-absorbing eyes" intelligently, provocatively, and inspiringly surveyed the world in which he lived to provide new sight to those in search of justice and humanity. Baldwin's resolute proclamations for racial equality and economic democracy as a black radical freedom writer were consequential during his own life and times, and continue to offer urgent encouragement today. ${ }^{26}$

\section{Notes}

1 Qtd. in Fern Marja Eckman, The Furious Passage of James Baldwin (New York, M. Evans, 1966), p. 26.

2 "The Last Interview: Interview by Quincy Troupe, St. Paul de Venice France, November 1987," in James Baldwin: The Last Interview and Other Conversations (New York, Melville House, 2014), pp. 80-1.

3 Horne's seminar that semester, “Twentieth Century African American History," featured 
works centered on black labor, black identity, black internationalism, and the black radical tradition, themes his own books addressed that appeared in 2005. See Gerald Horne, Red Seas: Ferdinand Smith and Radical Black Sailors in the United States and Jamaica (New York, New York University Press, 2005) and Black and Brown: African Americans and the Mexican Revolution, 1910-1920 (New York, New York University Press, 2005).

4 James Baldwin, "The White Man's Guilt," in Collected Essays, ed. Toni Morrison (New York, Library of America, 1998), pp. 722-3.

5 "James Baldwin to David Baldwin (February 6, 1979)," James Baldwin Letters and Manuscripts, Schomburg Center for Research in Black Culture, Manuscripts, Archives and Rare Books Division, The New York Public Library; David Leeming, James Baldwin: A Biography (New York, Knopf, 1994), p. 351.

6 Matt Bigg, "Baldwin's Memorial: 'We Have Seen His Righteous Witness,"' Collegian, 23 January 1988, pp. 17-18; "Memorial Service in Bowker Will Honor James Baldwin December 16," Campus Chronicle, 11 December 1987, p. 4; “'We Have Seen His Righteous Witness.' A Service in Appreciation, Respect, and Gratitude for James Arthur Baldwin, August 2, 1924-November 30, 1987," unprocessed files, W. E. B. Du Bois Department of Afro-American Studies, Special Collections and University Archives, University of Massachusetts, Amherst.

7 See "Freedom Rides," Martin Luther King Online Encyclopedia, http://kingencyclopedia.stanford.edu/encyclopedia/encyclopedia/enc_freedom_rides/index.html (accessed 8 September 2016); and Raymond Arsenault, Freedom Riders: 1961 and the Struggle for Racial Justice (New York, Oxford University Press, 2nd ed., 2011).

8 See James Baldwin, The Cross of Redemption: Uncollected Writings, ed. Randall Kenan (New York, Random House, 2010); James Baldwin, Jimmy's Blues and Other Poems, Introduction by Nikky Finney (Boston, MA, Beacon Press, 2014); and "Take This Hammer," KQED, San Francisco, 4 February 1964, San Francisco Bay Area Television Archives, San Francisco State University, https:/diva.sfsu.edu/collections/sfbatv/ bundles/187041 (accessed 8 Spetember 2016). The archive also contains a 2012 interview with the documentary director Richard O. Moore as well as a recently discovered director's cut, which includes an additional 15 minutes of the film that did not air in 1964 . While the Pacifica Radio Archives have not digitized all of its James Baldwin material, I used the following items in research for my Baldwin biography. James Baldwin, "Talk at the San Francisco Masonic Auditorium," 16 December 1964, Archive Number BB0370; James Baldwin, “100 Years of Freedom," 17 May 1963, Archive Number BB0637; "Baldwin Interviewed by Chris Koch," 1968, Archive Number BB4513; Elsa Knight Thompson and John Leonard, "A Conversation with James Baldwin," 7 May 1963, Archive Number BB0632; James Baldwin, “The Artist's Struggle for Integrity," 29 November 1962, Archive Number BB3641, Pacific Radio Archives, North Hollywood, California.

9 Conseula Francis, The Critical Reception of James Baldwin, 1963-2010: "An Honest Man and a Good Writer" (Rochester, N.Y., Camden House, 2014), p. 1.

10 Conseula Francis, "Reading and Theorizing James Baldwin: A Bibliographic Essay," James Baldwin Review, 1 (2015), p. 181.

11 For the idea of coherence through Baldwin's complexity, see Douglas Field, James Baldwin (Tavistock, Northcote, 2011), pp. 8-9, and All Those Strangers: The Art and Lives of James Baldwin (Oxford, Oxford University Press, 2015), p. 3.

12 Eckman, The Furious Passage of James Baldwin, p. 23.

13 Ibid., pp. 240-1. 
14 Randall Kenan and Amy Sickels, James Baldwin (Philadelphia, PA, Chelsea House, 2005), pp. 132-4. Kenan's book first appeared in 1994; Chelsea House reissued it in 2005. Also very useful is Randall Kenan, "James Baldwin, 1924-1987: A Brief Biography," in Douglas Field (ed.), A Historical Guide to James Baldwin (New York, Oxford University Press, 2009), pp. 21-60.

15 Ibid.

16 James Campbell, Talking at the Gates (New York, Penguin, 1991), p. 192.

17 Ibid., p. 225.

18 Leeming, James Baldwin.

19 Herb Boyd, Baldwin's Harlem: A Biography of James Baldwin (New York, Atria, 2008). For an important book of images, see Sedat Pakay, James Baldwin in Turkey: Bearing Witness from Another Place (Seattle, WA, University of Washington Press, 2012).

20 In conceiving of Baldwin as a black radical, I follow Bill Lyne's emphasis on his later career. See Bill Lyne, "God's Black Revolutionary Mouth: James Baldwin's Black Radicalism," Science \& Society, 74:1 (2010), pp. 12-36.

21 Amiri Baraka, "Jimmy!," in The LeRoi Jones/Amiri Baraka Reader, ed. William J. Harris (New York, Basic Books, 2009), pp. 450-6.

22 Ibid.

23 Ibid.

24 Ibid.

25 Morrison quoted in Kenan, “James Baldwin, 1924-1927: A Brief Biography," p. 22.

26 Justin A. Joyce, Dwight McBride, and Douglas Field, "Baltimore is Still Burning: The Rising Relevance of James Baldwin," James Baldwin Review, 1 (2015), pp. 1-9. Journalist Hannah K. Gold relates FBI surveillance of James Baldwin to documented evidence of U.S. surveillance of Black Lives Matter activists. See Hannah K. Gold, "Why Did the FBI Spy on James Baldwin?," The Intercept, 15 August 2015, https://theintercept. com/2015/08/15/fbi-spy-james-baldwin/ (accessed 8 September 2016).

\section{Archival Collections}

James Baldwin Letters and Manuscripts, Schomburg Center for Research in Black Culture, Manuscripts, Archives and Rare Books Division, The New York Public Library.

Pacifica Radio Archives, North Hollywood, California.

San Francisco Bay Area Television Archives, San Francisco State University.

W. E. B. Du Bois Department of Afro-American Studies Records (Unprocessed), University of Massachusetts at Amherst, Amherst, Massachusetts.

\section{Works Cited}

"Freedom Rides," Martin Luther King Online Encyclopedia, http://kingencyclopedia.stanford. edu/encyclopedia/encyclopedia/enc_freedom_rides/index.html (accessed 8 September 2016).

“The Last Interview: Interview by Quincy Troupe, St. Paul de Venice France, November 1987," in James Baldwin: The Last Interview and Other Conversations (New York, Melville House, 2014).

Arsenault, Raymond, Freedom Riders: 1961 and the Struggle for Racial Justice (New York, Oxford University Press, 2nd ed. 2011). 
Baldwin, James, The Cross of Redemption: Uncollected Writings, ed. Randall Kenan (New York, Random House, 2010).

_ Jimmy's Blues and Other Poems, Introduction by Nikky Finney (Boston, MA, Beacon Press, 2014).

_ "The White Man's Guilt," in Collected Essays, ed. Toni Morrison (New York, Library of America, 1998), pp. 722-3.

Baraka, Amiri, “Jimmy!" in The LeRoi Jones/Amiri Baraka Reader, ed. William J. Harris (New York, Basic Books, 2009), pp. 450-6.

Boyd, Herb, Baldwin's Harlem: A Biography of James Baldwin (New York, Atria, 2008).

Campbell, James, Talking at the Gates (New York, Penguin, 1991).

Eckman, Fern Marja, The Furious Passage of James Baldwin (New York, M. Evans, 1966).

Field, Douglas, All Those Strangers: The Art and Lives of James Baldwin (Oxford, Oxford University Press, 2015).

_ James Baldwin (Tavistock, Northcote, 2011).

Francis, Conseula, The Critical Reception of James Baldwin, 1963-2010: “An Honest Man and a Good Writer" (Rochester, N.Y., Camden House, 2014).

_ "Reading and Theorizing James Baldwin: A Bibliographic Essay," James Baldwin Review, 1 (2015), pp. 179-98.

Gold, Hannah K., “Why Did the FBI Spy on James Baldwin?” The Intercept, 15 August 2015, https://theintercept.com/2015/08/15/fbi-spy-james-baldwin/ (accessed 8 September 2016).

Horne, Gerald, Black and Brown: African Americans and the Mexican Revolution, 1910-1920 (New York, New York University Press, 2005).

Red Seas: Ferdinand Smith and Radical Black Sailors in the United States and Jamaica (New York, New York University Press, 2005).

Joyce, Justin A., Dwight McBride, and Douglas Field, "Baltimore is Still Burning: The Rising Relevance of James Baldwin," James Baldwin Review, 1 (2015), pp. 1-9.

Kenan, Randall, "James Baldwin, 1924-1987: A Brief Biography," in Douglas Field (ed.), A

Historical Guide to James Baldwin (New York, Oxford University Press, 2009), pp. 21-60.

Kenan, Randall, and Amy Sickels, James Baldwin (Philadelphia, PA, Chelsea House, 2005).

Leeming, David, James Baldwin: A Biography (New York, Knopf, 1994).

Lyne, Bill, “God's Black Revolutionary Mouth: James Baldwin’s Black Radicalism," Science \& Society, 74:1 (2010), pp. 12-36.

Pakay, Sedat, James Baldwin in Turkey: Bearing Witness from Another Place (Seattle, WA, University of Washington Press, 2012).

Weatherby, William J., James Baldwin: Artist on Fire (New York, Laurel, 1990).

\section{Contributor's Biography}

Phillip Luke Sinitiere is currently Visiting Assistant Professor of History at Sam Houston State University. In 2009, he received a Ph.D. in history from the University of Houston. A scholar of American religious history and African-American studies, his latest book is Salvation with a Smile: Joel Osteen, Lakewood Church, and American Christianity (NYU Press, 2015). His poem, "Wordplay: A Love Poem to Puns," appeared recently in Beacon. Currently, he is at work on a biography of James Baldwin and an article on the protest politics of the Sandra Bland movement. 